\title{
Karakteristik Ekstrak Pewarna Alami Bunga Kenop (Gomphrena globosa L.) pada Perlakuan Ukuran Partikel dan Lama Maserasi serta Korelasi Antar Variabel
}

The Characteristics of Natural Dye Extract Globe Amaranth (Gomphrena Globosa L.) on the Treatment of Particle Size and Maceration Time and Correlation between Variables

\author{
Rahel Br Ginting, Ni Made Wartini*, Luh Putu Wrasiati \\ PS Teknologi Industri Pertanian, Fakultas Teknologi Pertanian, Universitas Udayana, Kampus Bukit \\ Jimbaran, Badung, Kode pos : 80361; Telp/Fax : (0361) 701801.
}

Diterima 14 Agustus 2020 / Disetujui 24 Agustus 2020

\begin{abstract}
Natural dyes from globe amaranth contain betacyanin obtained through the extraction process. This study aims to know the characteristics of natural dye extract globe amaranth on the treatment of particle size and maceration time as well as determine the correlation between total betacyanin with the yield and color intensity of natural dyes extract globe amaranth. This research used two factors namely, particle size (40, 60, and 80 mesh) and maceration time (24, 36, and 48 hours). The data analysis used a bivariate correlation test. The results showed the characteristics of the natural dyes extract globe amaranth on the treatment of particle size and maceration time were as follows: yield 10.61-13.64 percent, total betacyanin $92.42-166.62 \mathrm{mg} / 100 \mathrm{~g}$, brightness level $\left(L^{*}\right) 18.03-13.09$, redness level $\left(a^{*}\right)$ 8.29-10.62, and yellowish level ( $\left.b^{*}\right)$ 3.85-7.66. Total betacyanin and yield have a strong but not significant correlation, with a coefficient correlation $(r) 0.6631$ and coefficient determination $\left(R^{2}\right)$ 0.4397 . The correlation between total betacyanin with color intensity namely, brightness $\left(L^{*}\right)$, redness $\left(a^{*}\right)$, and yellowish $\left(b^{*}\right)$ has a very strong and correlation with the coefficient correlation $(r)$ respectively -0.872; 0.877; and -8.836 and coefficient determination $\left(R^{2}\right)$ respectively $0.7701 ; 0.7608$; 0.7004 .
\end{abstract}

Keywords : Gomphrena globosa L., betacyanin, corelation, nature dyes, extraction

\section{ABSTRAK}

Pewarna alami dari bunga kenop mengandung betasianin yang diperoleh melalui proses ekstraksi. Penelitian ini bertujuan untuk mengetahui karakteristik ektrak pewarna alami bunga kenop pada perlakuan ukuran partikel dan lama maserasi serta menentukan korelasi antara total betasianin dengan rendemen dan intensitas warna ekstrak pewarna alami bunga kenop. Penelitian ini terdiri dari dua faktor yaitu ukuran partikel (40, 60, dan 80 mesh) dan lama maserasi (24, 36, dan 48 jam). Analisis data menggunakan uji korelasi bivariat. Hasil penelitian menunjukkan bahwa karakteristik pewarna alami bunga kenop (Gomphrena globosa L.) pada perlakuan ukuran partikel dan lama maserasi adalah sebagai berikut: rendemen 10,61-13,64 persen, total betasianin 92,4-166,62 mg/100g, tingkat kecerahan ( $\mathrm{L}^{*}$ ) 13,09-18,03, tingkat kemerahan (a*) 8,29-10,62, dan tingkat kekuningan $\left(\mathrm{b}^{*}\right)$ 3,85-7,66. Total betasianin dan rendemen memiliki korelasi yang kuat tetapi tidak signifikan, dengan nilai koefisien

\footnotetext{
*Korespondensi Penulis:

Email: md_wartini@unud.ac.id
} 
korelasi (r) sebesar 0,6631 dan koefisien determinasi $\left(\mathrm{R}^{2}\right)$ sebesar 0,4397 . Korelasi antara total betasinin dengan intensitas warna yaitu kecerahan $\left(\mathrm{L}^{*}\right)$, kemerahan $\left(\mathrm{a}^{*}\right)$, dan kekuningan $\left(\mathrm{b}^{*}\right)$ memiliki korelasi yang sangat kuat dan signifikan dengan nilai koefisien korelasi (r) secara berturut-turut yaitu $-0,872$; 0,877 ; dan $-0,836$ serta koefisien determinasi $\left(\mathrm{R}^{2}\right)$ secara berturut-turut yaitu 0,$7701 ; 0,7608,0,7004$.

Kata kunci : Gomphrena globosa L., betasianin, korelasi, pewarna alami, ekstraksi

\section{PENDAHULUAN}

Pewarna merupakan bagian penting dalam pembuatan produk makanan, karena pewarna dapat mempengaruhi penampilan dari produk tersebut. Pewarna alami adalah zat warna yang diperoleh dari tumbuhan, hewan, atau dari sumber-sumber mineral. Pigmen alami yang dapat digunakan sebagai pewarna yaitu betasianin. Salah satu sumber betasianin adalah bunga kenop (Heuter, 1992; Cai et al., 2001).

Tanaman bunga kenop (Gomphrena globosa L.) merupakan tanaman liar yang dapat tumbuh sampai ketinggian $1.400 \mathrm{~m}$ di atas permukaan laut dan juga pada tempattempat yang cukup mendapat sinar matahari (Wijayakusuma, 2000). Bunga kenop merupakan salah satu sumber betasianin. Betasianin merupakan pigmen yang mengandung nitrogen yang larut di dalam air yang termasuk dalam kelompok betalain. Betasianin memiliki warna antara merahungu (Strack et al., 2003). Pigmen betasianin hanya dapat ditemui pada beberapa tanaman dari anggota ordo Caryophyllales, termasuk Amaranthaceae, dan bersifat mutual eksklusif dengan pigmen antosianin (Grotewold, 2006). Betasianin dapat dimanfaatkan sebagai zat warna alami untuk pangan dan sebagai alternatif pengganti zat warna sintetik karena memiliki warna yang menarik, dan mempunyai aktivitas antioksidan yang tinggi sehingga lebih aman untuk tubuh apabila dikonsumsi (Kirsten et al., 2006). Bunga kenop mengandung komponen kimia alami yang berasal dari kelompok betasianin sebesar $1,3 \mathrm{mg} / \mathrm{g}$ sampel segar yang dapat dimanfaatkan sebagai sumber pewarna alami (Cai et al., 2001). Sehingga bunga kenop berpotensi untuk dijadikan sebagai sumber pewarna alami.

Ekstraksi merupakan teknik pemisahan kimia untuk memisahkan satu atau lebih komponen atau senyawa dari suatu sampel dengan menggunakan pelarut tertentu yang sesuai. Salah satu metode ekstraksi yang biasa digunakan adalah maserasi. Betasianin dapat diekstraksi menggunakan pelarut air, etanol, dan metanol, tetapi penggunaan pelarut air dalam proses pemekatan perlu diperhatikan karena penggunaan panas dapat mengakibatkan kerusakan senyawa betasianin sebab titik didih air cukup tinggi $\left(100^{\circ} \mathrm{C}\right)$. Betasianin sangat tidak stabil pada pemanasan suhu $70^{\circ} \mathrm{C}$ dan $80^{\circ} \mathrm{C}$ (Havlikova et al., 1983). Penelitian ekstraksi betasianin daun darah (Khuluq et al., 2007) menghasilkan kadar betasianin tertinggi sebesar 45,81 mg/100g dengan menggunakan etanol $48 \%$.

Ekstraksi dipengaruhi oleh beberapa faktor yaitu, ukuran partikel, jenis pelarut, lama ekstraksi, dan suhu. Faktor yang harus diperhatikan dalam proses ekstraksi betasianin ini diantaranya ukuran partikel dan lama maserasi. Semakin kecil ukuran partikel bahan cenderung memudahkan pelarut untuk mengekstrak senyawa aktif yang terdapat di dalam bahan. Hal tersebut dikarenakan, semakin kecil ukuran partikel bahan menyebabkan semakin banyak sel yang rusak sehingga memudahkan pelarut untuk menarik senyawa fitokimia dari bahan (Ketaren, 1986). Wulandari dan Suhartatik (2013), menyatakan bahwa ukuran partikel 60 mesh menghasilkan konsentrasi senyawa antosianin pada ekstrak kelopak bunga rosella lebih tinggi dibandingkan ukuran partikel 40 dan 80 mesh yaitu sebesar 211.9227 ppm. Sementara pada penelitian 
Putri et al. (2019), dalam proses pembuatan serbuk antosianin dari kubis merah dan bunga telang menggunakan ukuran partikel 80 mesh. Oleh karena itu, pada penelitian ini digunakan ukuran partikel 40 mesh, 60 mesh dan 80 mesh.

Faktor lain yang perlu diperhatikan dalam proses ekstraksi betasianin ini yaitu lama maserasi. Semakin lama waktu maserasi, maka senyawa yang terekstrak menjadi semakin banyak sampai batas tertentu. Hal ini disebabkan oleh waktu kontak antara bahan dan pelarut menjadi bertambah lama sehingga kemampuan pelarut untuk mengambil senyawa dalam bahan semakin optimal pula (Koirewoa et al., 2012). Penelitian Agne et al. (2010), ekstraksi betasianin pada kulit buah naga menggunakan waktu maserasi selama 24 jam. Penelitian Dwipayana (2019), menunjukkan bahwa lama waktu maserasi 36 jam merupakan perlakuan terbaik pada ektraksi klorofil daun pandan wangi. Sedangkan pada penelitian Sari et al. (2016), ekstraksi betasianin pada umbi bit menggunakan waktu maserasi selama 48 jam.

Korelasi digunakan untuk mengukur kekuatan hubungan antar variabel. Penelitian Putri et al. (2011), menunjukkan korelasi antara tingkat kecerahan dengan total klorofil menghasilkan nilai koefisien determinasi $\left(\mathrm{R}^{2}\right)$ sebesar 0,9926 dan koefisien korelasi (r) sebesar -0,9963 yang menunjukkan semakin besar jumlah klorofil terekstrak akan menurunkan nilai kecerahan. Penelitian Agustina (2016), tentang korelasi antara perbandingan ekstrak rosella dengan air kelapa dengan intensitas warna yang menghasilkan nilai koefisien determinasi $\left(\mathrm{R}^{2}\right)$ sebesar 0,75 dan koefisien korelasi (r) sebesar 0,886 yang menunjukkan adanya hubungan yang kuat antara kedua variabel.

Ekstraksi betasianin dari bunga kenop belum banyak dilakukan, oleh karena itu perlu dilakukan penelitian mengenai karakteristik ekstrak pewarna alami bunga kenop (Gomphrena globosa L.) pada perlakuan ukuran partikel dan lama maserasi serta korelasi antar variabel. Tujuan penelitian ini yaitu untuk mengetahui karakteristik ekstrak pewarna alami bunga kenop pada perlakuan ukuran partikel dan lama maserasi serta menentukan korelasi antara total betasianin dengan rendemen dan intensitas warna ekstrak pewarna alami bunga kenop.

\section{METODE PENELITIAN}

\section{Tempat dan Waktu}

Penelitian ini dilakukan di Laboratorium Rekayasa Proses dan Pengendalian Mutu, Laboratorium Analisis Pangan, dan Laboratorium Teknik Pasca Panen, Fakultas Teknologi Pertanian, Universitas Udayana. Waktu pelaksanaan mulai Januari hingga Maret 2020.

\section{Bahan dan Alat}

Peralatan yang digunakan dalam penelitian ini antara lain ayakan 40 mesh, 60 mesh, dan 80 mesh (Retsch), blender (Philips), rotary evaporator (Buchi R-300 tipe $V)$, color reader (Accuprobe HH-O6), timbangan analitik (Shimadzu), oven (Blue M), spektrofotometer (Biochrome SN 133467), vortex (Barnstead Thermolyne Maxi Mix II), kertas saring kasar, kertas saring Whatman No. 1, dan alat-alat gelas lainnya.

Bahan yang digunakan dalam penelitian ini yaitu bunga kenop (Gomphrena globosa L.) berwarna ungu seragam dengan diameter kelopak 22-25 mm yang diperoleh Jalan Sedap Malam, Desa Kesiman, Kecamatan Denpasar Timur, Kota Denpasar. Bahan kimia yang digunakan yaitu akuades (Bratachem), etanol teknis 96\% (Bratachem), dan buffer sitrat pH 5 (pa) (E. Merck).

\section{Rancangan Percobaan}

Percobaan pada penelitian ini terdiri 
atas dua faktor. Faktor pertama yaitu ukuran partikel yang terdiri dari tiga taraf yaitu $\mathrm{S} 1$ : 40 mesh, S2: 60 mesh, dan S3: 80 mesh. Faktor kedua yaitu lama maserasi yang terdiri atas tiga taraf, yaitu T1: 24 jam, T2: 36 jam, dan T3: 48 jam. Dari 2 faktor diatas diperoleh 9 kombinasi perlakuan dan dianalisis sebanyak dua kali (duplo). Data obyektif yang diperoleh dianalisis dengan menggunakan program Ms. Excel 2016 dan uji korelasi menggunakan program SPSS 25. Data disajikan dalam bentuk grafik.

\section{Pelaksanaan Penelitian Pembuatan sampel}

Bunga kenop yang berwarna ungu seragam dengan diameter kelopak 22-25 mm, selanjutnya dicuci hingga bersih dan dihilangkan bagian kelopaknya. Selanjutnya diblansing selama 1 menit dengan suhu $95 \pm 2^{\circ} \mathrm{C}$ (Pangesti, 2018). Kemudian bunga kenop didinginkan dengan air mengalir. Selanjutnya bunga kenop dikeringkan dengan suhu $40 \pm 5^{\circ} \mathrm{C}$ menggunakan oven sampai mudah untuk dihancurkan (kadar air 7,3\%). Setelah kering, dihaluskan menggunakan blender. Kemudian bubuk bunga kenop diayak menggunakan ayakan 40 mesh, 60 mesh, dan 80 mesh.

\section{Ekstraksi Bunga Kenop}

Bunga kenop yang sudah diayak sesuai perlakuan (40, 60 dan 80 mesh) ditimbang sebanyak 20 gram kemudian ditambahkan pelarut etanol 48\% sebanyak $220 \mathrm{~mL}$ (1:11) (b/v) (Yudharini, 2016). Kemudian dilakukan maserasi sesuai perlakuan yaitu 24 jam, 36 jam dan 48 jam. Pengadukan dilakukan manual setiap 6 jam selama 5 menit dengan suhu ruangan $28 \pm 2^{\circ} \mathrm{C}$, sehingga diperoleh ekstrak yang masih tercampur dengan pelarut. Selanjutnya ekstrak yang masih bercampur pelarut disaring menggunakan kertas saring kasar yang menghasilkan filtrat I dan ampas. Kemudian ampas ditambah pelarut sebanyak $20 \mathrm{~mL}$ diaduk selama 5 menit, lalu disaring dengan kertas saring kasar dan menghasilkan filtrat II. Filtrat I dan II dicampur dan disaring dengan kertas saring Whatman No. 1. Ekstrak yang diperoleh kemudian dimasukkan ke dalam labu rotary evaporator dan dievaporasi pada suhu $50^{\circ} \mathrm{C}$ dengan tekanan 100 mBar. Evaporasi dihentikan pada saat semua pelarut sudah menguap yang ditandai dengan tidak adanya tetesan pelarut. Ekstrak kental yang diperoleh dimasukkan ke dalam wadah sampel.

\section{Variabel yang Diamati}

Variabel yang diamati dalam penelitian ini antara lain rendemen ekstrak (Sudarmadji et al., 1989), total betasianin (Eder, 1996), dan intensitas warna sistem $\mathrm{L}^{*}, \mathrm{a}^{*}, \mathrm{~b}^{*}$ (Weaver, 1996).

\section{Rendemen Ekstrak (Sudarmadji et al., 1989)}

Rendemen ekstrak dapat dihitung dengan cara berat ekstrak bunga kenop dibagi dengan berat bubuk bunga kenop dikalikan dengan $100 \%$. Rumus perhitungan rendemen ekstrak bunga kenop yaitu:

Rendemen ekstrak $(100 \%)=$

$\underline{\text { Berat ekstrak bunga kenop (g) }} \times 100 \%$

Berat bubuk bunga kenop (g)

\section{Total Betasianin (Eder, 1996)}

Penentuan kadar total betasianin dengan metode Eder (1996). Sebanyak 0,01 g ektrak bunga kenop ditimbang lalu dilarutkan dengan buffer sitrat $\mathrm{pH} 5$ sebanyak $5 \mathrm{~mL}$ kemudian dihomogenkan menggunakan vortex. Kemudian dibaca pada spektofotometer (Biochrome SN 133467) dengan panjang gelombang $537 \mathrm{~nm}$ dan 600 nm. Nilai absorbansi dihitung dengan $\mathrm{A}=$ $1,095$ ( $\lambda 537$ - $\lambda 600)$. Rumus perhitungan total betasianin pada bunga kenop yaitu:

Total betasinin $(\mathrm{mg} / \mathrm{L})=\underline{\mathrm{A} \times \mathrm{MW} \times \mathrm{Df} \times 1000}$ $\varepsilon \times \mathrm{L}$

Keterangan :

A : Absorbansi

Df : Faktor pengenceran

MW : Berat molekul $550 \mathrm{~g} / \mathrm{mol}$ 
$\varepsilon \quad$ : Koefisien ekstinsi molar betasianin $(60000 \mathrm{~L} / \mathrm{mol} \mathrm{cm})$

L : Tebal kuvet $(1 \mathrm{~cm})$

Total betasinin $(\mathrm{mg} / 100 \mathrm{~g})=$

$\frac{\mathrm{X} \times \mathrm{V} \times \mathrm{FP} \times 1000 \times 100}{\mathrm{~W}}$

Keterangan :

$\mathrm{X}$ : Konsentrasi persamaan awal

$\mathrm{V}$ : Volume (L)

W : Berat sampel (mg)

\section{Intensitas Warna (Sistem L*, $\mathbf{a}^{*}, \mathbf{b}^{*}$ dalam Weaver, 1996)}

Pengukuran intensitas warna dari ekstrak bunga kenop dilakukan dengan menggunakan color reader. Pembacaan dilakukan dengan menghidupkan color reader pada tombol pembacaan $\mathrm{L}^{*}, \mathrm{a}^{*}, \mathrm{~b}^{*}$. Dimana, $\mathrm{L}^{*}$ untuk parameter kecerahan (lightness), a* tingkat kemerahan dan $\mathrm{b}^{*}$ untuk tingkat kekuningan. Intensitas warna diukur dengan menekan tombol target.

\section{HASIL DAN PEMBAHASAN}

\section{Rendemen}

Rendemen ekstrak pewarna alami bunga kenop (Gomphrena globosa L.) pada perlakuan ukuran partikel dan lama maserasi berkisar antara 10,61 - 13,64 persen dapat dilihat pada Gambar 1.

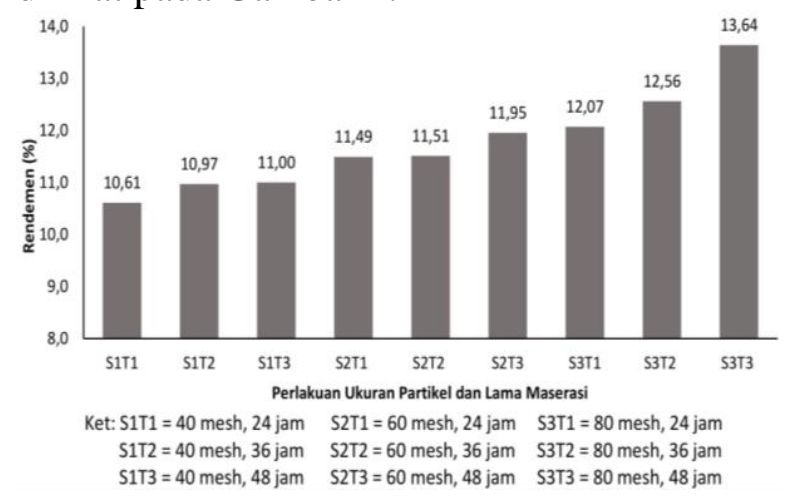

Gambar 1. Rendemen (\%) ekstrak bunga kenop pada perlakuan ukuran partikel dan lama maserasi

Gambar 1 menunjukkan rendemen ekstrak bunga kenop tertinggi diperoleh dari ukuran partikel 80 mesh dan lama maserasi 48 jam yaitu 13,64 persen, sedangkan rendemen terendah diperoleh dari ukuran partikel 40 mesh dan lama maserasi 24 jam yaitu 10,6 persen. Hasil ini menunjukkan bahwa semakin kecil ukuran partikel yang digunakan maka rendemen yang didapatkan semakin banyak. Ukuran partikel yang semakin kecil akan memperluas bidang kontak antara bahan dengan pelarut. Luas bidang kontak yang lebih besar dengan pelarut menyebabkan lebih banyak terjadinya tumbukan dengan pelarut yang mengakibatkan senyawa pada bahan lebih banyak berdifusi sehingga rendemen menjadi lebih besar (Hutapea et al., 2014). Hasil ini didukung oleh penelitian Maulida dan Any (2015), mengenai pengaruh ukuran partikel beras hitam terhadap rendemen ekstrak dan kandungan total antosianin menghasilkan rendemen tertinggi pada perlakuan ukuran partikel 40 mesh dari perlakuan ukuran partikel beras utuh, 20 mesh, dan 40 mesh.

Perlakuan lama maserasi dapat dilihat adanya kenaikan rendemen pada setiap kenaikan waktu maserasi. Hal ini menunjukkan bahwa semakin lama waktu yang digunakan maka semakin tinggi rendemen yang dihasilkan. Hasil ini didukung oleh penelitian Amanda dan Ika (2017) tentang pengaruh waktu maserasi terhadap rendemen zat antosianin pewarna alami minuman jelly dari terong ungu yang menunjukkan bahwa semakin lama maserasi yang dilakukan maka akan memperbesar jumlah senyawa yang terlarut dan mengakibatkan laju ekstraksi semakin meningkat. Menurut Koirewoa et al. (2012), bahwa semakin lama maserasi, maka senyawa yang terekstrak menjadi semakin banyak sampai senyawa dalam bahan habis terekstrak. Hal ini disebabkan oleh waktu kontak antara bahan dan pelarut menjadi bertambah lama sehingga kemampuan pelarut untuk mengambil senyawa dalam 
bahan semakin optimal pula.

\section{Total Betasianin}

Total betasianin ekstrak bunga kenop dengan perlakuan ukuran partikel dan lama maserasi berkisar antara 92,42 $\pm 0,57-$ $166,62 \pm 0,48 \mathrm{mg} / 100 \mathrm{~g}$, dapat dilihat pada Gambar 2.

Gambar 2 menunjukkan total betasianin ekstrak bunga kenop tertinggi diperoleh dari ukuran partikel 80 mesh dan lama maserasi 36 jam yaitu 166,62 $\pm 0,48$ $\mathrm{mg} / 100 \mathrm{~g}$, sedangkan total betasianin ekstrak bunga kenop terendah diperoleh dari ukuran partikel 40 mesh dan lama maserasi 24 jam yaitu $92,42 \pm 0,57 \mathrm{mg} / 100 \mathrm{~g}$.

Hasil ini menunjukkan bahwa semakin kecil ukuran partikel dan semakin lama waktu

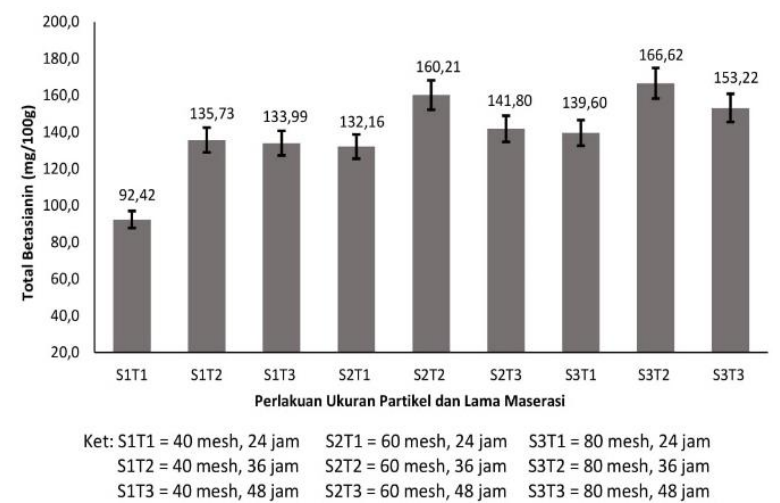

Gambar 2. Total betasianin ekstrak bunga kenop pada perlakuan ukuran partikel dan lama maserasi

maserasi yang digunakan meningkatkan total betasianin.Namun pada waktu maserasi 48 jam kadar betasianin mengalami penurunan hal ini kemungkinan disebabkan terjadinya kerusakan betasianin pada waktu maserasi yang lebih lama. Hal ini didukung oleh penelitian Paranoan et al. (2017), ekstraksi betasianin pada kulit buah naga merah menghasilkan kadar betasianin tertinggi pada waktu maserasi 3 hari dan pada waktu maserasi 5 hari mengalami penurunan. Hal ini dikarenakan waktu maserasi yang terlalu lama mengakibatkan terjadinya degradasi pigmen sehingga menurunkan kadar betasianin di dalamnya.

Menurut Ketaren (1986), semakin kecil ukuran partikel bahan yang digunakan akan menyebabkan semakin banyak sel yang rusak sehingga memudahkan pelarut untuk menembus dinding sel dan menarik senyawa aktif dari bahan. Begitu juga dengan lama waktu maserasi semakin lama waktu maserasi, maka semakin lama pula kontak antara bahan dan pelarut sehingga kuantitas bahan yang terekstrak juga akan semakin meningkat. Hal ini dikarenakan kesempatan untuk bersentuhan antara bahan dengan pelarut semakin besar sehingga hasilnya akan bertambah sampai titik jenuh larutan (Winata dan Yunianta, 2015). Penelitian yang dilakukan oleh Cai et al. (2001), mengenai identifikasi senyawa betasianin, diperoleh kadar betasianin pada bunga kenop segar sebesar $1,3 \mathrm{mg} / \mathrm{g}$ atau setara dengan 130 $\mathrm{mg} / 100 \mathrm{~g}$.

\section{Tingkat Kecerahan $\left(\mathbf{L}^{*}\right)$}

Tingkat kecerahan ekstrak bunga kenop dengan perlakuan ukuran partikel dan lama maserasi berkisar antara 13,09 $\pm 0,24$ 18,03 $\pm 0,11$ dapat dilihat pada Gambar 3 . Nilai (L*) menyatakan tingkat gelap sampai terang dengan kisaran $0-100$.

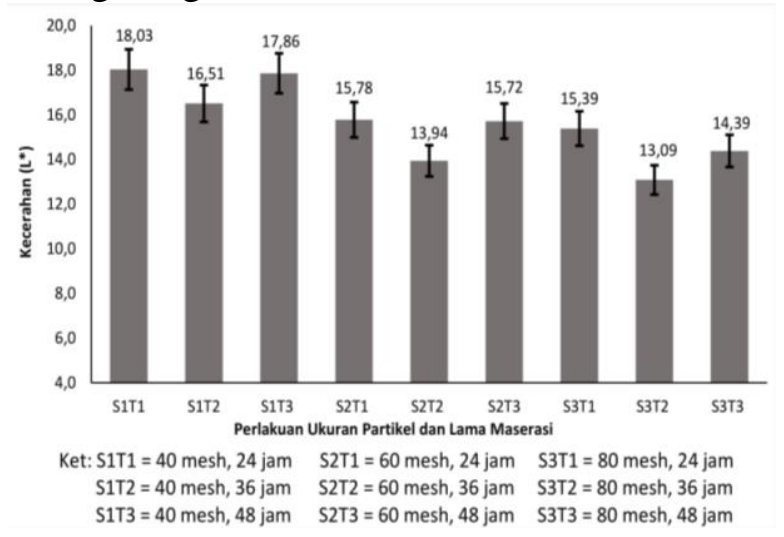

Gambar 3. Tingkat kecerahan (L*) ekstrak bunga kenop pada perlakuan ukuran partikel dan lama maserasi 
Gambar 3 menunjukkan tingkat kecerahan ekstrak bunga kenop tertinggi diperoleh dari perlakuan ukuran partikel 40 mesh dan lama maserasi 24 jam yaitu $18,03 \pm 0,11$, sedangkan tingkat kecerahan ekstrak bunga kenop terendah diperoleh dari ukuran partikel 80 mesh dan lama maserasi 36 jam yaitu 13,09 $\pm 0,24$. Hasil ini menunjukkan bahwa tingkat kecerahan ekstrak bunga kenop berbanding terbalik dengan total betasianin. Hal ini disebabkan oleh ekstrak bunga kenop pada perlakuan ukuran partikel 80 mesh dan lama maserasi 36 jam menghasilkan total betasianin yang tinggi dan mengakibatkan kenampakan ekstrak semakin gelap. Ekstrak bunga kenop dengan perlakuan ukuran partikel 40 mesh dan lama maserasi 24 jam menghasilkan total betasianin yang rendah sehingga diperoleh tingkat kecerahan yang tinggi. Hal ini dikarenakan hasil ekstraksi bunga kenop dengan total betasianin yang lebih rendah menyebabkan warna ekstrak tidak terlalu gelap. Selain itu juga terjadi kerusakan betasianin akibat dari dekomposisi struktur pigmen yang terjadi karena semakin lamanya proses ekstraksi sehingga terjadi pemucatan dan menyebabkan warna semakin terang (Khuluq et al., 2007). Menurut Herbach et al. (2006) tentang perubahan warna dari jus pitaya bahwa peningkatan nilai $\mathrm{L}^{*}$ menunjukkan bahwa terjadinya kerusakan pada betasianin.

\section{Tingkat Kemerahan (a*)}

Tingkat kemerahan ekstrak bunga kenop dengan perlakuan ukuran partikel dan lama maserasi berkisar antara 8,29 $\pm 0,21-$ 10,62 $\pm 0,16$ dapat dilihat pada Gambar 4 . Nilai (a*) menyatakan tingkat warna hijau sampai merah dengan kisaran -100 sampai +100 .

Gambar 4 menunjukkan tingkat kemerahan ekstrak bunga kenop tertinggi diperoleh dari perlakuan ukuran partikel 80 mesh dan lama maserasi 36 jam yaitu
10,62 $\pm 0,16$, sementara tingkat kemerahan ekstrak bunga kenop terendah diperoleh dari ukuran partikel 40 dan lama maserasi 24 jam yaitu 8,29 $\pm 0,21$. Hasil ini menunjukkan bahwa pada perlakuan ukuran partikel 40 mesh dan ukuran partikel 60 mesh betasianin belum terekstrak dengan sempurna begitu pula pada lama maserasi 24 jam, sementara pada lama maserasi 48 jam betasianin mengalami penurunan stabilitas. Hal ini mengakibatkan terjadi kerusakan dan menurunkan kadar betasianin sehingga terjadi penurunan intensitas warna merah.

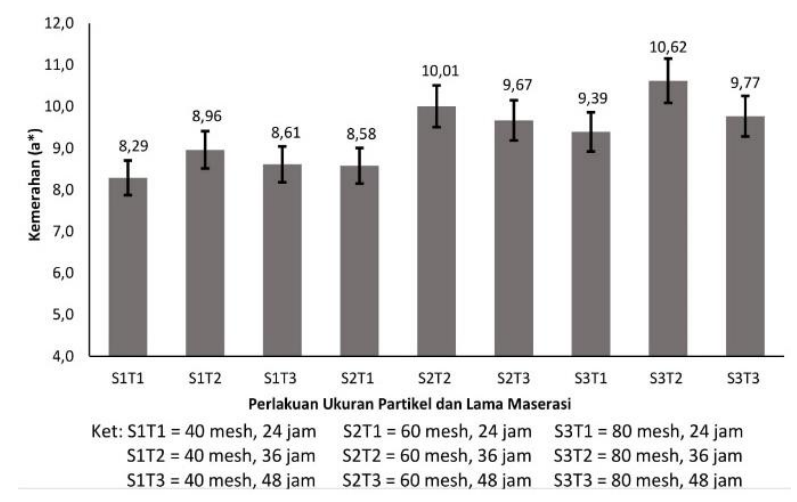

Gambar 4. Tingkat kemerahan ( $\left.a^{*}\right)$ ekstrak bunga kenop pada perlakuan ukuran partikel dan lama maserasi

Perlakuan ukuran partikel 80 mesh dan lama maserasi 36 jam menghasilkan total betasianin pada ekstrak bunga kenop tertinggi dibandingkan dengan perlakuan yang lain sehingga hubungan antara betasianin dengan tingkat kemerahan berbanding lurus. Semakin tinggi konsentrasi betasianin yang dihasilkan maka akan menghasilkan intensitas warna merah semakin tinggi pula (Khuluq et al., 2007).

\section{Tingkat Kekuningan (b*)}

Tingkat kekuningan ekstrak bunga kenop dengan perlakuan ukuran partikel dan lama maserasi berkisar antara 3,85 $\pm 0,16-$ 7,66 $\pm 0,13$ dapat dilihat pada Gambar 5 . Nilai $\left(b^{*}\right)$ menyatakan tingkat warna biru sampai kuning dengan kisaran -100 sampai +100 . 


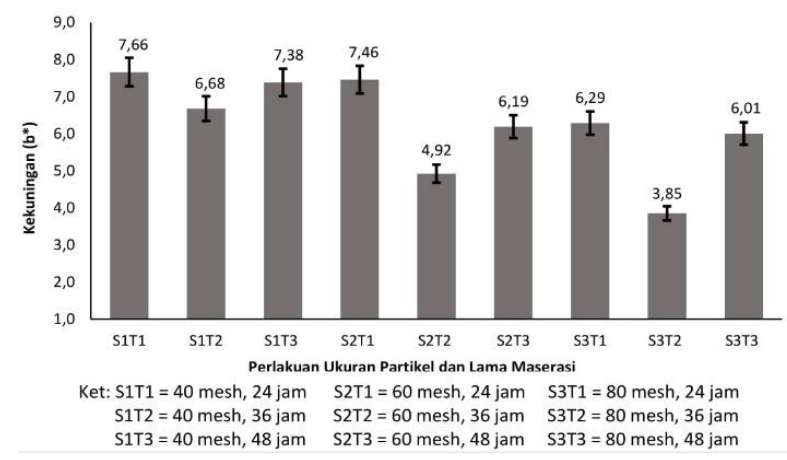

Gambar 5. Tingkat kekuningan (b*) ekstrak bunga kenop pada perlakuan ukuran partikel dan lama maserasi

Gambar 5 menunjukkan tingkat kekuningan ekstrak bunga kenop tertinggi diperoleh dari perlakuan ukuran partikel 40 mesh dan lama maserasi 24 jam yaitu 7,66 \pm 0,13 , sedangkan tingkat kekuningan ekstrak bunga kenop terendah diperoleh dari ukuran partikel 80 mesh dan lama maserasi 36 jam yaitu $3,85 \pm 0,16$. Semakin lama waktu ekstraksi tingkat kekuningan mengalami penurunan.

Hal tersebut berkaitan dengan kadar betasianin yaitu saat kadar betasianin tinggi maka tingkat kekuningan rendah. Hal ini disebabkan karena betasianin memberikan pengaruh warna merah yang lebih besar dibandingkan warna kuning (Khuluq et al., 2007).

\section{Korelasi Total Betasianin (x) dengan Rendemen (y)}

Hasil analisis korelasi total betasianin dengan rendemen pada perlakuan ukuran partikel dan lama maserasi ekstrak bunga kenop dapat dilihat pada Gambar 6.

Gambar 6 menunjukkan persamaan regresi linear antara total betasianin (y) dengan rendemen $(\mathrm{x})$ yaitu $\mathrm{Y}=0,0289 \mathrm{x}+$ 7,725 dengan nilai koefisien determinasi $\mathrm{R}^{2}=$ 0,4397 dan koefisien korelasi $\mathrm{r}=0,6631$.

Koefisien korelasi sebesar $r=0,6631$ menunjukkan bahwa adanya korelasi yang kuat antara total betasianin dengan rendemen. Hal ini sesuai dengan Sarwono (2006), yang menyatakan bahwa nilai koefisien korelasi dengan rentang antara 0,5-0,75 menunjukkan korelasi yang kuat. Koefisien korelasi yang dihasilkan bernilai positif ini artinya total betasianin memiliki hubungan searah dengan rendemen, yaitu semakin tinggi total betasianin maka semakin tinggi pula rendemen yang dihasilkan.

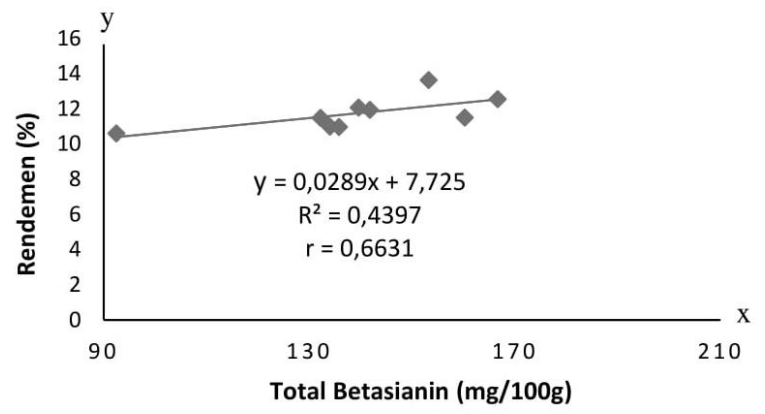

Gambar 6. Grafik kolerasi antara total betasianin dengan rendemen

Nilai signifikansi yang dihasilkan yaitu 0,052 . Hasil ini menunjukkan bahwa nilai sig. $=0,052>0,01$, artinya total betasianin memiliki hubungan tidak signifikan dengan rendemen. Nilai koefisien determinasi $\left(\mathrm{R}^{2}\right)$ dari persamaan ini menyatakan bahwa $43,97 \%$ rendemen dipengaruhi oleh total betasianin sedangkan sekitar 53,03\% dipengaruhi oleh variabel lain.

\section{Korelasi Total Betasianin (x) dengan Intensitas Warna $\left(L^{*}, a^{*}, b^{*}\right)(\mathbf{y})$}

Hasil analisis korelasi antara total betasianin dengan intensitas warna yaitu tingkat kecerahan (a), tingkat kemerahan (b) dan tingkat kekuningan (c) ekstrak bunga kenop pada perlakuan ukuran partikel dan lama maserasi dapat dilihat pada Gambar 7.

Gambar 7 menunjukkan persamaan regresi linear antara total betasianin dengan tingkat kecerahan, tingkat kemerahan, dan tingkat kekuningan secara berturut-turut yaitu $\mathrm{y}=-0,0682 \mathrm{x}+25,157 ; \mathrm{y}=0,0315 \mathrm{x}+$ 4,9216 ; dan $y=-0,0488 x+13,079$. Koefisien korelasi antara total betasianin dengan tingkat kecerahan, tingkat kemerahan, dan tingkat kekuningan berturut-turut yaitu $r=-0,872 ; r$ $=0,877$ dan $r=-0,836$. Nilai ini menunjukkan bahwa adanya hubungan yang sangat kuat 
antara total betasianin dengan intensitas warna.

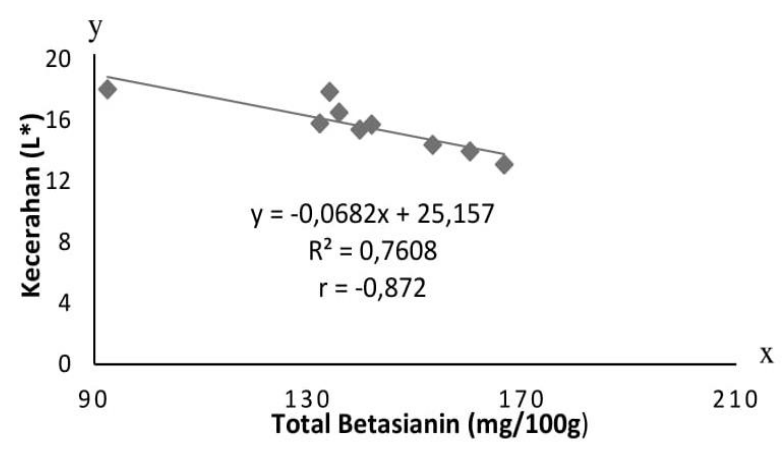

(a) tingkat kecerahan

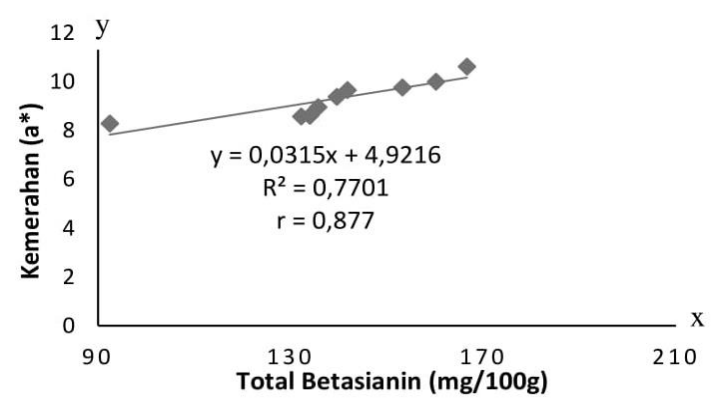

(b) tingkat kemerahan

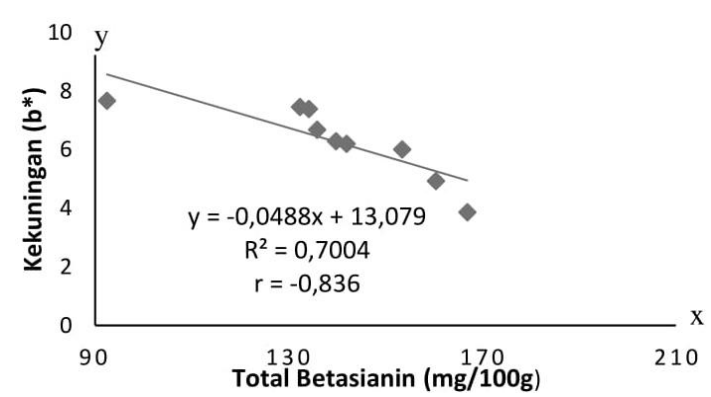

(c) tingkat kekuningan

Gambar 7. Grafik kolerasi antara betasianin dengan intensitas warna

Hal ini sesuai dengan Sarwono (2006) yang menyatakan bahwa nilai koefisien korelasi dengan rentang antara 0,75-0,99 menunjukkan korelasi yang sangat kuat. Koefisien korelasi yang dihasilkan antara total betasianin dengan tingkat kemerahan bernilai positif. Hal ini menunjukkan bahwa semakin tinggi nilai total betasianin maka semakin tinggi pula tingkat kemerahan yang dihasilkan. Hasil ini sesuai dengan Herbach et al. (2006) yang menyatakan bahwa kenaikan dan penurunan intensitas warna merah ekstrak dipengaruhi oleh besar kecilnya kadar betasianin yang terdapat pada bahan.

Koefisien korelasi yang dihasilkan antara total betasianin dengan tingkat kecerahan dan tingkat kekuningan bernilai negatif. Hal ini menunjukkan bahwa yaitu semakin tinggi nilai total betasianin maka semakin rendah tingkat kecerahan, begitu pula sebaliknya. Hasil ini sesuai dengan penelitian Putri et al. (2011), pada korelasi antara tingkat kecerahan dengan total klorofil menghasilkan nilai koefisien korelasi (r) sebesar -0,9963 yang menunjukkan semakin besar jumlah klorofil terekstrak akan menurunkan nilai kecerahan. Penelitian Agustina (2016), korelasi antara perbandingan ekstrak rosella dan air kelapa dengan intensitas warna yang menghasilkan koefisien korelasi (r) sebesar 0,886 yang menunjukkan adanya hubungan yang kuat antara kedua variabel. Nilai koefisien korelasi (r) yang positif menunjukan bahwa hubungan antara perbandingan ekstrak rosella dengan air kelapa memberikan arti semakin tinggi formulasi ekstrak rosella akan menyebabkan semakin tinggi nilai total antosianin yang dihasilkan dan semakin merah warna minuman yang dihasilkan.

Nilai signifikansi antara total betasianin dengan tingkat kecerahan, tingkat kemerahan dan tingkat kekuningan yaitu 0,$002 ; 0,002$; 0,005 . Hasil ini menunjukkan bahwa ketiganya memiliki nilai signifikansi yang lebih kecil dari 0,01. Hal ini berarti bahwa total betasianin memiliki hubungan signifikan dengan tingkat kecerahan, tingkat kemerahan dan tingkat kekuningan dengan tingkat kepercayaan $99 \%$.

Nilai koefisien determinasi $\left(\mathrm{R}^{2}\right)$ tertinggi yaitu pada korelasi antara total betasianin dengan tingkat kemerahan sebesar 0,7701 . Hal ini menunjukkan bahwa $77,01 \%$ tingkat kemerahan dipengaruhi oleh total betasianin sedangkan sekitar 22,99\% dipengaruhi oleh variabel lain. Sementara 
nilai koefisien determinasi $\left(\mathrm{R}^{2}\right)$ pada korelasi antara total betasianin dengan tingkat kecerahan memiliki nilai sebesar 0,7608 yang berarti bahwa 76,08\% tingkat kecerahan dipengaruhi oleh total betasianin sedangkan sekitar 23,92\% dipengaruhi oleh variabel lain. Begitu juga dengan hubungan total betasianin dengan tingkat kekuningan memiliki nilai koefisien determinasi $\left(\mathrm{R}^{2}\right)$ sebesar 0,7004 yang berarti bahwa 70,04\% tingkat kekuningan dipengaruhi oleh total betasianin, sedangkan sekitar 29,96\% dipengaruhi oleh variabel lain. Hasil ini sesuai dengan penelitian Agustina (2016), yaitu pada korelasi antara perbandingan ekstrak rosella dan air kelapa dengan intensitas warna yang menghasilkan koefisien determinasi $\left(\mathrm{R}^{2}\right)$ sebesar 0,75 yang menunjukkan bahwa $75 \%$ ekstrak rosella dipengaruhi oleh intensitas warna, sementara sekitar 25\% dipengaruhi oleh faktor lainnya. Penelitian Kristamtini et al. (2017) mengenai korelasi kandungan antosianin total dengan peubah warna $\left(\mathrm{L}^{*}, \mathrm{a}^{*}, \mathrm{~b}^{*}\right)$ dan penanda mikrosatelit pada beras hitam menghasilkan koefisien determinasi $\left(\mathrm{R}^{2}\right)$ sebesar 0,77, artinya, 77,0\% keragaman yang muncul pada kandungan antosianin dapat dijelaskan oleh variabel warna $\left(\mathrm{L}^{*}, \mathrm{a}^{*}, \mathrm{~b}^{*}\right)$ dan $23,0 \%$ sisanya faktor lain selain variabel warna $\mathrm{L}^{*}$, $a^{*}$, dan $b^{*}$.

\section{KESIMPULAN}

\section{Kesimpulan}

1. Karakteristik ekstrak pewarna alami bunga kenop (Gomphrena globosa L.) pada perlakuan ukuran partikel dan lama maserasi adalah sebagai berikut: rendemen 10,61-13,64 persen, total betasianin $92,42-166,62 \mathrm{mg} / 100 \mathrm{~g}$, tingkat kecerahan (L*) 18,03-13,09, tingkat kemerahan $\left(\mathrm{a}^{*}\right)$ 8,29-10,62 dan tingkat kekuningan $\left(b^{*}\right) 3,85-7,66$.

2. Total betasianin dan rendemen memiliki korelasi yang kuat tetapi tidak signifikan, dengan nilai koefisien korelasi (r) sebesar 0,6631 dan koefisien determinasi $\left(\mathrm{R}^{2}\right)$ sebesar 0,4397. Korelasi antara total betasinin dengan intensitas warna, yaitu tingkat kecerahan $\left(\mathrm{L}^{*}\right)$, kemerahan $\left(\mathrm{a}^{*}\right)$, dan kekuningan $\left(b^{*}\right)$ memiliki korelasi yang sangat kuat dan signifikan dengan nilai koefisien korelasi (r) secara berturutturut yaitu $-0,872 ; 0,877$; dan $-0,836$ serta koefisien determinasi $\left(\mathrm{R}^{2}\right)$ berturut-turut sebesar 0,7701; 0,7608; 0,7004.

\section{Saran}

Berdasarkan hasil penelitian ini disarankan untuk penelitian lebih lanjut terhadap stabilitas ekstrak pewarna alami bunga kenop dan pengaplikasian ekstrak pewarna alami bunga kenop pada bahan pangan.

\section{DAFTAR PUSTAKA}

Agne, E.B.P., R. Hastuti dan Khabibi. 2010. Ekstraksi dan uji kestabilan zat warna betasianin dari kulit buah naga (Hylocereus polyrhizus) serta aplikasinya sebagai pewarna alami pangan. Jurnal Kimia Sains dan Aplikasi. 13(2):51-56.

Agustina,Y. 2016. Kajian Korelasi Suhu Pasteurisasi Dan Perbandingan Ekstrak Rosella (Hibiscus sabdariffa) dengan Air Kelapa (Cocos nucifera) terhadap Intensitas Warna dan Antioksidan Menggunakan Analisis Regresi Linier. Skripsi. Tidak dipublikasi. Fakultas Teknik, Universitas Pasundan, Bandung.

Amanda, A. dan I. Kurniaty. 2017. Pengaruh waktu maserasi terhadap rendemen zat antosianin pewarna alami minuman jelly dari terong ungu. Seminar Nasional Sains dan Teknologi. Fakultas Teknik Universitas Muhammadiyah, Jakarta. 
Cai, Y., M. Sun and H. Corke. 2001. Identification and distribution of simple andacylated betacyanins in the Amarantaceae. Journal of Food Agricultural and Food Chemistry. 49:1971-1978.

Dwipayana, I.M., N.M. Wartini dan L.P. Wrasinati. 2019. Pengaruh perbandingan bahan dengan pelarut dan lama ekstraksi terhadap karakteristik ekstrak pewarna daun pandan wangi (Pandanus amaryllifolius Roxb.). Jurnal Rekayasa dan Manajemen Agroindustri. 7(4): 571-580.

Eder, R. 1996. Handbook of Food Analysis, Vol I. Marcel Dekker Inc, New York.

Estiasih, T., dan K. Ahmadi. 2014. Teknologi Pengolahan Pangan. Bumi Aksara, Jakarta.

Havlikova, L., K. Mikova and Kyzlink. 1983. Heat stability of betacyanins. Lebensm Unters Forsch. 177: 247- 50.

Herbach, K. M., F. C. Stinizing and R. Carle. 2006. Betalain stability and degradation structural and chromatic aspects. Journal of Food Science. 71(4):41-50.

Heuter, S. 1992. Betacyanins from flowers of Gomphrena globosa. Phytochemistry. 31(5): 1801-1807.

Hutapea, E.R.F., L.O.Siahaan, R.Tambun. 2014. Ekstraksi pigmen antosianin dari kulit rambutan (Nephelium lappaceum) dengan pelarut metanol. Jurnal Teknik Kimia. 3(2):34-40.

Ketaren, S. 1986. Pengantar Teknologi Minyak dan Lemak Pangan. Universitas Indonesia Press, Jakarta.

Khuluq, A.D., S.B. Widjarmoko dan E.S. Murtini. 2007. Ekstraksi dan stabilitas betasianin daun darah (Althernathera dentate) kajian pelarut etanol : air dan suhu ekstraksi. Jurnal Teknologi Pertanian. 8(3):172-181.

Kirsten, M., Herbach, F. C. Stintzing and R. Carle. 2006. Betalain stability and degradation structural and chromatic aspects. Journal of Food Science. 71(4):41-50.

Koirewoa, Y. A., Fatimawali, dan W. I. Wiyono. 2012. Isolasi dan identifikasi senyawa flavonoid dalam daun beluntas (Pluchea indica L.). J. Pharmacon. 1(1):47-52.

Kristamtini, Taryono, P. Basunanda, dan R. H. Murti. 2017. Korelasi kandungan antosianin total dengan peubah warna $\left(L^{*}, a^{*}\right.$, dan $\left.b^{*}\right)$ dan penanda mikrosatelit pada beras hitam. Jurnal Penelitian Pertanian Tanaman Pangan. 1(2): 115-124.

Leba, M.A.U. 2017. Ekstraksi dan Real Kromatografi. Deepublish, Yogyakarta.

Maulida, R. dan A. Guntarti. 2015. Pengaruh ukuran partikel beras hitam (Oryza sativa L.) terhadap rendemen ekstrak dan kandungan total antosianin. Journal of Pharmaciana. 5(1): 9-16.

Pangesti, D.R.H. 2018. Identifikasi Pigmen dan Aktivitas Antioksidan Ekstrak Buah Naga. Skripsi. Tidak dipublikasi. Fakultas Teknologi Pertanian, Institut Pertanian Bogor, Bogor.

Paranoan, C.A.C., Lahming, Kadirman. 2017. Optimalisasi konsentrasi asam tartrat dan waktu ekstraksi pada ekstraksi pigmen betasianin dari kulit buah naga merah (Hylocereus polyrhizus) sebagai pewarna alami. Jurnal Pendidikan Teknologi Pertanian. 3(1):126-133

Putri, N. I., M. J. Chance, P. A. C. Rahardjo, V. K. Ananingsih. 2019. Pengaruh jenis dan konsentrasi enkapsulan dalam 
proses pembuatan serbuk antosianin dari kubis merah dan bunga telang. Jurnal Teknologi Pangan dan Gizi. 18 (1):1- 9 .

Putri, W.D.R., E. Zubaidah, N. Sholahudin. 2011. Ekstraksi pewarna alami daun suji, kajian pengaruh blanshing dan jenis bahan pengekstrak. Jurnal Teknologi Pertanian. 4(1):13-25.

Sari, N.M.I., A.M. Hudha dan W. Prihanta. 2016. Uji kadar betasianin pada buah bit (Beta vulgaris L.) dengan pelarut etanol dan pengembangannya sebagai sumber belajar biologi. Jurnal Pendidikan Biologi. 2(1):72-77.

Sarwono, J. 2006. Metode Penelitian Kuantitatif dan Kualitatif. Graha Ilmu, Yogyakarta.

Strack, D., T. Vogt and W. Schliemann. 2003. Recent advances in betalain research. Phytochemistry. 62:247-269.

Sudarmadji, S., B. Haryono dan Suhardi. 1989. Analisa Bahan Makanan dan Pertanian. Liberty, Yogyakarta.

Sudarmadji, S., B. Haryono dan Suhardi. 1997. Prosedur Analisa untuk Bahan Makanan dan Pertanian. Liberty, Yogyakarta.

Sugiyono. 2007. Metode Penelitian Administrasi. Alfabeta, Bandung.

Weaver, C. 1996. The Food Chemistry Laboratory. CRC Press, Boca Raton.

Wijayakusuma, H.M.H. 2000. Ensiklopedia Milenium Tumbuhan Berkhasiat Obat Indonesia. Prestasi Insan Indonesia, Jakarta.

Winarno. 2002. Pangan Gizi Teknologi Konsumen. PT. Gramedia Pustaka Utama, Jakarta.
Winata E. W., dan Yunianta. 2015. Ekstraksi antosianin buah murbei (Morus alba L.) metode ultrasonic bath (kajian waktu dan rasio bahan : pelarut). Jurnal Pangan dan Agroindustri. 3(2):773783.

Wulandari, W.Y. dan Suhartatik. 2013. Pengaruh suhu pemanasan dan ukuran mesh dalam ekstraksi senyawa antosianin kelopak bunga rosella (Hibiscus sabdariffa L.). Prosiding Seminar Nasional Pangan dan Kesehatan Masyarakat. LPPM UNISRI, Surakarta.

Yudharini, G.A.K.F., A.A.P.A. Suryawan, dan N.M. Wartini. 2016. Pengaruh perbandingan bahan dengan pelarut dan lama ekstraksi terhadap rendemen dan karakteristik ekstrak pewarna dari buah pandan (Pandanus tectorius). Jurnal Rekayasa dan Manajemen Agroindustri. 4(3): 36-46.

Yusmita, L., A. Kasim, dan H. Nurdin. 2017. Pengaruh suhu ekstraksi dan konsentrasi asam sitrat terhadap pigmen betacyanin daun kremah merah (Alternanthera dentata) dan aplikasinya pada pangan. Jurnal Ilmu dan Teknologi Pangan. 3(1):178-185. 